\title{
USEFULNESS OF MANAGEMENT ACCOUNTING SYSTEMS INFORMATION AND MARKET COMPETITION ON STRATEGIC BUSINESS UNIT OUTPUT
}

\author{
STIE Trisakti \\ yulius@tsm.ac.id
}

YULIUS KURNIA SUSANTO

\begin{abstract}
Abstrak: The research examines the interaction effect between the intensity of market competition and the usefulness of broad scope and timeliness management accounting systems (MAS) information characteristics on strategic business unit (SBU) performance and job satisfaction. Fifty six SBU managers from manufacturing industry in Java and Sumatra had participated in the research. The collecting data used a questionnaire survey via electronic-mail and post. Data were analyzed using a moderated regression analysis. The results showed that the higher the intensity of market competition, the more positive the relationship between the usefulness of timeliness MAS information characteristic, SBU performance and job satisfaction. On the contrary the effect of the intensity of market competition on the relationship between the usefulness of broad scope MAS information characteristic, SBU performance and job satisfaction was not significant.
\end{abstract}

Keywords: Broad scope, timeliness, management accounting systems information, intensity of market competition, strategic business unit performance and job satisfaction.

\section{INTRODUCTION}

One of tools is used management to face the business competition is management accounting systems representing facility of supporter function yielding relevant and timely information for the planning, control, decision 
making and performance evaluation. The information enables the management to implement strategy and to do the operational activity which is needed to achieve the organizational target as a whole.

Some studies of management accounting use the contingency approach was used to evaluate the organizational external factors (e.g. intensity of market competition, organizational technology change and environmental uncertainty) what is anticipated can cause the SAM become more effective (Gul 1991, Faisal 2006). Some research previously tried to identify the contextual variables, such as perceived environmental uncertainty (PEU) (Gul 1991), decentralizes and PEU (Gul and Chia 1994), task uncertainty (Chong 1996), strategy and PEU (Chong and Chong 1997), intensity of market competition (Mia and Clarke 1999, Ikhsan 2006, Susanto and Gudono 2007), environmental uncertainty and organization structure (Supardiyono 1999), business strategy and environmental uncertainty (Desmiyawati 2001), task uncertainty (Azmi 2003), PEU (Agbejule 2005), task uncertainty and organization culture (Nurnaluri 2005) and intensity of market competition, strategy and PEU (Faisal 2006) that possible influence the relationship between MAS information and performance and job satisfaction.

The research uses the intensity of market competition as contextual variable in influencing the relationship between usefulness of MAS information and outcome variable like performance and job satisfaction. The reasons of research uses the intensity of market competition are first, market competition has created the turbulence, pressure, risk and company uncertainty. Second, culminate the company demand that is replying all threat and opportunity in competition environment to design and use the correct control system to achieve the target. There are some empirical evidence supporting the effect of intensity of market competition on relationship between usefulness of MAS information and performance (e.g. Bromwich 1990, Mia and Clarke 1999, Susanto and Gudono 2007).

Bromwich (1990) argued that MAS information assists the company to challenge the competitive market focusing on improvement of company added value so that exceeding competitor. According to MAS information and requirement of decision maker will improve the decision quality to be taken and in the end will improve the SBU performance. Result of Mia and Clarke's (1999) study expressing that usefulness of MAS information could assist the company for the implementation of their plans in response of competitive environmental. While other study using intensity of market competition in other context is Chong et al. (2001) argued that intensity of market competition influence the relationship between budgetary participation 
and managerial performance and job satisfaction. Result of prior studies showed that intensity of market competition representing external factor of company could influence the relationship between the usefulness of MAS information and SBU performance and job satisfaction.

The organization of writing was prepared with the following first, introduction describing the background of the problem, research objectives and organization of writing. Second, contingency theory and previous research. Third, the research method consists of sample selection and data collection, operational definitions and measurement variables. Fourth, the research results that contain the results of hypothesis testing. Finally, conclusions, limitations and recommendations for future research.

\section{THEORITICAL FRAMEWORK AND HYPOTHESIS DEVELOPMENT}

\section{Contingency Theory}

Contingency approach on management accounting systems pursuant to common premise that there was no system or concept of management accounting which was universally (wherever or in a condition any kind) can be used a organization effectively; a concept of accountancy management only according to or compatible (fit) for the context and condition of just certain (Riyanto 1999). Simons (1987) identified this relationship as a prerequisite to develop theoretical of MAS design. A lot of studies have been applying contingency theory to analyze and design the control system (Otley 1980) specially in MAS field which was attributed with contextual variables, such as environmental uncertainty (Gordon and Narayanan 1984), technology complexity (Chenhall and Morris 1986), business strategy (Simons 1987, Abernethy and Guthrie 1994, Chong and Chong 1997), perceived Environmental Uncertainty (PEU) (Gul 1991), task uncertainty (Chong 1996), intensity of market competition (Mia and Clarke 1999), and strategic uncertainty (Riyanto 2003).

Contingency approach is drawing researcher enthusiasm because they wish to know whether level of the MAS reliability will always have an equal effect on performance in each condition or not. By pursuant to level of contingency, there is anticipation that there are contextual factors to interact in harmony with certain condition that faced. 


\section{Management Accounting Systems Information}

Atkinson et al. (1995) argued that management accounting yields useful information to assist manager in decision making that better. Traditionally, management accounting information was predominated by finance information, but in growth of information non finance (Banker et al. 2000) and determine the competent information to improve the understanding of problems and reduce the uncertainty was happened because difference between information was required and available in decision making (Galbraith 1973) in Agbejule (2005). Management Accounting Systems (MAS) researcher defined MAS as a formal system designed for providing information to facilitate decision making and evaluation of managerial activity (Chenhall 2003).

The result of research of Chenhall and Morris (1986) found empirical evidence was about characteristic of useful MAS information that was broad scope, timeliness, aggregation and integration. Broad scope and timeliness information characteristics become attention in this research which was summarized on Table 1 as follows:

Table 1

Characteristic of MAS information

\begin{tabular}{ll}
\hline Dimension & Sub-dimension \\
\hline Broad Scope & External information \\
& Non-financial information \\
& Future-oriented (e.g., probabilistic) \\
Timeliness & $\begin{array}{l}\text { Frequency of reporting } \\
\text { Speed of reporting }\end{array}$ \\
& Reporting on intra-sub-unit interactions \\
\hline
\end{tabular}

Source: Chenhall and Morris (1986)

Intensity of market competition on the relationship between MAS information and Strategic Business unit performance and Job satisfaction

Gordon and Narayan (1984) said that information of Management Accounting Systems (MAS) have important role for decision making if it was related by uncertainty environment condition. It was supported by Chenhall and Morris (1986), mention that there was relationship between the usefulness of broad scope and timeliness MAS information characteristics and the environmental uncertainty.

Manager activity which different will result the difference of information requirement having the character of broad scope to make decision 
more effective so that yield the better managerial performance. Gordon and Narayan (1984) said that information orienting to future is necessary for manager to face and control uncertainty. Timeliness information characteristic can lessen the uncertainty because can assist the manager continually accommodates all its activity as respond to all changes. Time accuracy forwarding MAS information can influence the ability manager to make decision more precise because manager able to accommodate all its activity to condition faced.

Intensity of market competition was one of environmental uncertainty factor (Gul 1991). More intensive of market competition, organization will improve differentiation of product, degradation of product life cycle, introduce new channel, facing improvement of sensitivities market, and improve product goals (Rolfe 1992). The change made competitive challenge, so SBU will adaptive the strategy include product differentiation, service and price (Linn 1994).

Mia and Clarke (1999) said that competition of market influences using of MAS information which can increase SBU performance. Pursuant to the research pickings can be concluded that manager who facing uncertainty situation, for examples market competitive, MAS information which was used as base of decision making will improve SBU performance and job satisfaction. MAS is information system which is collecting financial data and non financial data then that data is processed, kept, and reported to manager for base of decision making. It is integral part from an organization which is related with structure and organization process, for produces control of organization include manager control. MAS and good control system for organization is influenced by intensity of market competition. The difference of competition type (price, channel of marketing, and product) has differential influence to using information MAS and system of organization control. Manager used the information MAS for decision making. It's about product pricing, market demand forecasting, market planning, purchasing of raw material, product planning and improvement of organization infrastructure (Mia and Clarke 1999).

The prior researches gave empirical evidence that using sophisticated information MAS more used when facing uncertainty high situation, for example intensity of market competition (Gordon and Narayanan 1984, Chenhall and Morris 1986, Gul 1991, Ikhsan 2006, Susanto and Gudono 2007, Susanto 2008). In high condition of the intensity of market competition, manager need the sophisticated MAS information for decision making what more precise, so it can increase SBU performance. The traditional accountan- 
cy information and the less sophisticated MAS information were used more precise by manager for decision making in low condition of the intensity of market competition. If manager uses the sophisticated MAS information for facing low condition of the intensity of market competition, SBU performance will be decrease. It is caused by MAS information which be used too abundant (Gul 1991). The using sophisticated MAS information will improve SBU performance in high condition of the intensity of market competition but in low condition, SBU performance will be decrease. So it can be made hypothesis, as follows:

$\mathrm{H}_{1 \mathrm{a}}$ The higher intensity of market competition, the more positive is the relationship between the usefulness of broad scope MAS information characteristic and SBU performance.

$\mathrm{H}_{1 \mathrm{~b}}$ The higher intensity of market competition, the more positive is the relationship between the usefulness of timeliness MAS information characteristic and SBU performance.

The job satisfaction is somebody attitude to their work (Dewar and Werbel 1979). That attitude comes from their perception to their work. The job satisfaction of somebody can be from availability level of organization resource for support their work, for example the availability information which support to decision making. The information is result where from a MAS (for examples no economics information, information on time, information to analyze the profit increase, and integrated information). It is used by organization manager to make a decision in so many situations, for example the intensity of market competition.

The level of suitability between availability MAS information and the intensity of market competition can make a perception of manager's satisfaction to their work. If managers are faced in high condition of the intensity of market competition, using sophisticated MAS information to decision making can make the job satisfaction. The using sophisticated MAS information will improve job satisfaction in high condition of the intensity of market competition but it will decrease job satisfaction in low condition. So it can be made hypothesis, as follows:

$\mathrm{H}_{2 \mathrm{a}}$ The higher intensity of market competition, the more positive is the relationship between the usefulness of broad scope MAS information characteristic and job satisfaction.

$\mathrm{H}_{2 b}$ The higher intensity of market competition, the more positive is the relationship between the usefulness of timeliness MAS information characteristic and job satisfaction. 


\section{RESEARCH METHODS}

\section{Sample Selection and Collecting Data}

The research sample was taken from manufacturing industries which enlisted in Indonesia Stock Exchange. The research respondents were the SBU managers of manufacturing industry. The reason of respondent election because they were managers of strategic business unit who do routine activity and their performance was measured by the goals attainment of each. The strategic business units can be defined as an organization or part of organization which have routine activity, like marketing part, production, financial, personnel and research and development (Mia and Clarke 1999). The collecting data used a questionnaire survey via electronic-mail and post. The sum of questionnaire which was sent to respondent was five hundred and thirty and which can be processed are fifty six questionnaires. It which can be assumed has completed condition for processing data and the population deputizing in this research. It is suitable for respond rate of prior researches in Indonesia which is classified low is equal ten percent up to sixteen percent (Mardiyah and Gudono 2001).

\section{Operational Definition and Variable Measurement}

Management Accounting Systems (MAS) is information system which is collecting operational data and financial, processing, keeping, and reporting to user (Atkinson et al. 1995). MAS information is measured by using nine items instrument with seven point of likert scale developed by Chenhall and Morris (1986). The respondents were asked to arrange grades in a rank availability of MAS information on their business unit. The point one deputized not available information MAS and point seven deputized available information MAS so many. Cronbach alpha of broad scope MAS is 0.759 and timeliness is 0.623 .

The intensity of market competition is defined as factors which influences emulation level, it is measured from number of major competitors operating in the market, frequency of technological change in the industry, frequency of new product introduction, extent of price cut, package deals for customers offered by competitors and changes in government regulation or policy and tariff reductions, intensity price competition, intensity product competition (differentiation), promotion of product and channel of distribution (Khandawalla 1972, Chong et al. 2001). This variable was measured by using instrument which was developed by Chong et al. (2001), adopted 
from Mia and Clarke (1999) and Khandawalla's research (1972). This instrument contained four questions concerning intensity of market competition with using seven points of scale likert. The point one deputized the condition of market competition which was very low and point seven deputized the condition of market competition which was very high. Cronbach alpha of intensity of market competition is 0.793

The Strategic Business unit performance was defined by Mia and Clarke (1999) as how high level of attainment goals which have been planned, for example attainment of production, cost, quality, delivery of product, service, volume of sale, market segment and profit level. This variable was measured by the instrument developed by Mia and Clarke (1999) with seven points of scale likert. This instrument contained eight questions concerning organization performance. The respondents were asked to assess their average SBU performance which was compared than the other average SBU performance what of a kind. The point one deputized the performance below average and point seven deputized the performance above average. Cronbach alpha of SBU performance is 0.792 .

The job satisfaction is the form of individual satisfaction to their work and also the form hobby to work in an organization (Chong et al. 2001). The job satisfaction was measured by two questions with seven point of scale likert developed by Dewar and Werbel (1979). This instrument has been used by prior accounting research (Chong et al. 2001). The point one deputized not satisfied and point seven deputized very satisfied. Cronbach alpha of job satisfaction is 0.697 .

\section{RESEARCH RESULT}

The descriptive statistics presented in Table 1 and Table 2 shows the correlation matrix for the variables used in this study as follows: 
Table 1 Descriptive Statistics

\begin{tabular}{lccccc}
\hline \multicolumn{1}{c}{ Variable } & Mean & $\begin{array}{c}\text { Standard } \\
\text { Deviation }\end{array}$ & Median & $\begin{array}{c}\text { Actual } \\
\text { Range }\end{array}$ & $\begin{array}{c}\text { Theoretical } \\
\text { Range }\end{array}$ \\
\hline $\begin{array}{l}\text { Broad scope } \\
\text { Timeliness }\end{array}$ & 4.6310 & 0.9378 & 4.7500 & $2-7$ & $1-7$ \\
$\begin{array}{l}\text { Intensity of } \\
\text { market }\end{array}$ & 4.4688 & 0.8983 & 4.5000 & $2.75-6$ & $1-7$ \\
$\begin{array}{l}\text { competition } \\
\text { SBU }\end{array}$ & 4.6230 & 0.8070 & 4.5556 & $2.22-6.22$ & $1-7$ \\
$\begin{array}{l}\text { performance } \\
\text { Job satisfaction }\end{array}$ & 4.9152 & 0.5509 & 4.7500 & $4.00-6.38$ & $1-7$ \\
\hline
\end{tabular}

Table 2 Correlation Matrix

\begin{tabular}{|c|c|c|c|c|c|}
\hline Variable & 1 & 2 & 3 & 4 & 5 \\
\hline (1) Broad scope & 1 & & & & \\
\hline (2) Timeliness & $0.665 * *$ & 1 & & & \\
\hline $\begin{array}{l}\text { (3) Intensity of market } \\
\text { competition }\end{array}$ & $0.643^{* *}$ & $0.516 * *$ & 1 & & \\
\hline (4) SBU performance & $0.330 *$ & $0.478 * *$ & $\begin{array}{l}0.397 * \\
*\end{array}$ & 1 & \\
\hline (5) Job satisfaction & $0.336 *$ & $0.442 * *$ & 0.258 & $0.571^{* *}$ & 1 \\
\hline
\end{tabular}

Before testing hypotheses, researcher will see what there the differences were of sample characteristic (seen from broad scope and timeliness MAS information characteristics, intensity of market competition, SBU performance and job satisfaction) between respondent which response through electronic-mail and post. The result of independent-samples test shows that there were no differences of sample characteristic between respondent which response through electronic-mail and post.

The hypotheses were tested using moderated regression analysis (see Hartmann and Moers 1999), based on the following multiplicative model: 


$$
\begin{aligned}
& \mathrm{Y}_{1}=\mathrm{b}_{0}+\mathrm{b}_{1} \mathrm{X}_{1}+\mathrm{b}_{2} \mathrm{X}_{2}+\mathrm{b}_{3} \mathrm{X}_{3}+\mathrm{b}_{4} \mathrm{X}_{1} \mathrm{X}_{3}+\mathrm{b}_{5} \mathrm{X}_{2} \mathrm{X}_{3}+e \\
& \mathrm{Y}_{2}=\mathrm{b}_{0}+\mathrm{b}_{1} \mathrm{X}_{1}+\mathrm{b}_{2} \mathrm{X}_{2}+\mathrm{b}_{3} \mathrm{X}_{3}+\mathrm{b}_{4} \mathrm{X}_{1} \mathrm{X}_{3}+\mathrm{b}_{5} \mathrm{X}_{2} \mathrm{X}_{3}+e
\end{aligned}
$$

Where $Y_{1}$ SBU performance, $Y_{2}$ job satisfaction, $X_{1}$ broad scope MAS information, $\mathrm{X}_{2}$ timeliness MAS information, $\mathrm{X}_{3}$ intensity of market competition and $e$ error term.

Hypothesis 1a (1b) which states that the higher the intensity of market competition, the more positive is the relationship between the usefulness of broad scope (timeliness) MAS information characteristic and SBU performance, was tested by examining the sign and significance of the coefficient of the interaction term $b_{4}\left(b_{5}\right)$ in equation (1). To support hypothesis $1 \mathrm{a}(1 \mathrm{~b})$, the coefficient $\mathrm{b}_{4}\left(\mathrm{~b}_{5}\right)$ in equation (1) should be positive, indicating a significant interaction exists between the usefulness of broad scope (timeliness) MAS information characteristic and intensity of market competition affecting SBU performance. The results presented in Table 3 shows that first, the coefficient $\mathrm{b}_{4}$ was negative and not significant ( $t$-value $=-1.204, p<0.234$, 1-tailed), providing initial not support for the study's hypothesis 1a. Second, the coefficient $b_{5}$ was positive and significant $(t$-value $=2.107, p<0.040,1$ tailed), providing initial support for the study's hypothesis $1 \mathrm{~b}$.

Table 3 Results of regression SBU performance on MAS information and intensity of market competition

\begin{tabular}{lccc}
\hline \multicolumn{1}{c}{ Variable } & Coefficient & t-value & P (1-tailed) \\
\hline Constant & 6.611 & 3.394 & 0.001 \\
Broad scope $\left(\mathrm{X}_{1}\right)$ & 0.556 & 1.036 & 0.305 \\
Timeliness $\left(\mathrm{X}_{2}\right)$ & -1.142 & -1.706 & 0.094 \\
Intensity of market competition $\left(\mathrm{X}_{3}\right)$ & -0.551 & -1.287 & 0.204 \\
$\mathrm{X}_{1} * \mathrm{X}_{3}$ & -0.142 & -1.204 & 0.234 \\
$\mathrm{X}_{2} * \mathrm{X}_{3}$ & 0.308 & 2.107 & 0.040 \\
\hline $\mathrm{R}^{2}=0.330 ;$ Adjusted $\mathrm{R}^{2}=0.263 ; \mathrm{F}_{5,50}=4.927 ; p$-value $<0.001 ;$ \\
Kolmogorov-Smirnov $\mathrm{Z}$ residual= 0.498 p-value $=0.482 ;$
\end{tabular}

The prediction model in equation (1) accounts for $26.3 \%$ of the variation (Adjusted $R^{2}=0.263 ; \mathrm{F}_{5,50}=4.927 ; p<0.001$ ) in SBU performance. The result of testing first hypothesis indicated that the higher the intensity of market competition, the more positive is the relationship between the usefulness of timeliness MAS information characteristic and SBU performance. On the contrary the effect of the intensity of market competition on the 
relationship between the usefulness of broad scope MAS information characteristic and SBU performance was not significant.

Hypothesis 2a (2b) which states that the higher the intensity of market competition, the more positive is the relationship between the usefulness of broad scope (timeliness) MAS information characteristic and job satisfaction, was tested by examining the sign and significance of the coefficient of the interaction term $b_{4}\left(b_{5}\right)$ in equation (2). To support hypothesis $2 \mathrm{a}(2 \mathrm{~b})$, the coefficient $\mathrm{b}_{4}\left(\mathrm{~b}_{5}\right)$ in equation (2) should be positive, indicating a significant interaction exists between the usefulness of broad scope (timeliness) MAS information characteristic and intensity of market competition affecting job satisfaction. The results presented in Table 4 shows that first, the coefficient $\mathrm{b}_{4}$ was negative and not significant ( $t$-value $=-0.924, p<$ $0.360,1$-tailed), providing initial not support for the study's hypothesis 2a. Second, the coefficient $b_{5}$ was positive and significant ( $t$-value $=2.251, p<$ 0.029, 1-tailed), providing initial support for the study's hypothesis $2 \mathrm{~b}$.

\section{Table 4 Results of regression Job satisfaction on MAS information and intensity of market competition}

\begin{tabular}{lccc}
\hline \multicolumn{1}{c}{ Variable } & Coefficient & t-value & P (1-tailed) \\
\hline Constant & 9.879 & 3.341 & 0.002 \\
Broad scope $\left(\mathrm{X}_{1}\right)$ & 0.777 & 0.952 & 0.346 \\
Timeliness $\left(\mathrm{X}_{2}\right)$ & -1.928 & -1.897 & 0.064 \\
Intensity of market competition $\left(\mathrm{X}_{3}\right)$ & -1.458 & -2.241 & 0.029 \\
$\mathrm{X}_{1} * \mathrm{X}_{3}$ & -0.165 & -0.924 & 0.360 \\
$\mathrm{X}_{2} * \mathrm{X}_{3}$ & 0.500 & 2.251 & 0.029 \\
\hline $\mathrm{R}^{2}=0.294$; Adjusted $\mathrm{R}^{2}=0.223 ; \mathrm{F}_{5,50}=4.157 ; p$-value $<0.003 ;$ \\
Kolmogorov-Smirnov $Z$ residual $=0.518$-value $=0.475 ;$
\end{tabular}

The prediction model in equation (2) accounts for $22.3 \%$ of the variation (Adjusted $R^{2}=0.223 ; \mathrm{F}_{5,50}=4.157 ; p<0.003$ ) in job satisfaction. The result of testing second hypothesis indicated that the higher the intensity of market competition, the more positive is the relationship between the usefulness of timeliness MAS information characteristic and job satisfaction. On the contrary the effect of the intensity of market competition on the relationship between the usefulness of broad scope MAS information characteristic and job satisfaction was not significant. 


\section{CONCLUSION, LIMITATIONS AND RECOMMENDATION}

The research gave empirical evidence that using timeliness MAS information would increase SBU performance and job satisfaction in high condition of the intensity of market competition but in low condition it would decrease SBU performance and job satisfaction. On the contrary the effect of the intensity of market competition on the relationship between the usefulness of broad scope MAS information characteristic and SBU performance and job satisfaction was not significant. The research successful confirmed the result of research of Mia and Clarke (1999), Chong et al. (2001), Ikhsan (2006), Susanto and Gudono (2007). The research implication that organizational designer required to consider the uncertainty condition (example intensity of market competition) for designing and implementation management accounting system which was providing information to facilitate decision making and evaluating managerial activity, so that would improve the managerial performance, job satisfaction and SBU performance.

The research had some limitation which possible can bother the result of research, for example (1) The research only focuses on using broad scope and timeliness MAS information characteristics. The result of research of Chenhall and Morris (1986) found empirical evidence was about characteristic of useful MAS information that was broad scope, timeliness, aggregation and integration; (2) Collecting data used the questionnaire survey via electronic-mail and post. The questionnaire was sent by mailing list on yahoo groups, there were possibility be filled by not expected respondent; (3) Taking research sample which only comes from manufacturing industry caused less varying of sample perception. The characteristic of homogeneous would influence result of research; (4) SBU manager which their company had unfavorable performance, there were tendency not to participate in this research. This thing was proven by the existence of questionnaire which was not responded.

From some limitations mentioned above, the result of the research is expected can push next researches. The research will be done next which is expected can fix the limitation of the research with consider some factors, for example (1) model of this research can explain the variance of SBU performance and job satisfaction, each were $26.3 \%$ and $22.3 \%$. This thing shows that there are the other variables which can influence SBU performance and job satisfaction except MAS information and intensity of market competition. Example of those other variables is product customization (Bouwens and Abernethy 2000), locus of control (Chong and Eggleton 1996) and leadership style (Jiambalvo and Pratt 1982); (2) Need the different samples 
not only take the samples from manufacturing industry, but also service and trade industry; (3) Do survey with the direct interview to SBU manager, so that can be gotten respondent and level of respond which really be expected.

\section{REFERENCES:}

Abernethy, M. A. and Guthrie, C. H. 1994. An Empirical Assessment of the "fits" Between Strategy and Management Information System Design. Accounting and Finance, Vol.34, pp.49-66.

Agbejule, Adebayo. 2005. The Relationship between Management Accounting Systems and Perceived Environmental Uncertainty on Managerial Performance: A Research Note. Accounting and Business Research, Vol.15, No.4, pp.295-305.

Atkinson, AA., RJ Banker, RS. Kaplan and SM. Young. 1995. Management Accounting. Englewood Cliftts, New Jersey: Prrentice-Hall.

Azmi, Zul. 2003. Pengaruh Ketidakpastian Tugas terhadap hubungan antara Karakteristik Sistem Akuntansi Managemen and Kinerja Mangerial. Thesis (tidak dipublikasikan), Program Pasca Sarjana UGM, Jogjakarta.

Banker, RD., Gordon, P. and Dhinu, Srinivasan. 2000. An Empirical Investigation of an Incentive Plan that Includes Nonfinancial Perforamnce Measures. The Accounting Review, Vol.75, No.1, pp.65-92.

Bouwens, J. and Abernethy, MA. 2000. The Consequences of Customization on Management Accounting System Design. Accounting, Organization and Society, Vol.25, pp.221-241.

Bromwich, M. 1990. The Case for Strategic Management Accounting: The Role of Accountting information for Strategy in Competitive Markets. Accounting Organization and Society.Vol. 15. pp.27-46.

Chenhal, RH. and Morris, D. 1986. The Impact of Structure, Environment, and Interdependence on Perceived Usefulness of Management Accounting Systems. The Accounting Review, Vol.61, pp.16-35.

Chenhall, RH. 2003. Management Control System design within its organizational context. Findings form contingency-based research and directions for future. Accounting, Organization and Society, Vol.28, pp.127-168.

Chong, VK. 1996. Management Accounting Systems, Task Uncertainty and Managerial Performance: A Research Note. Accounting, Organization and Society, Vol.21, pp.415-421.

Chong, VK. and Ian RC. Eggleton. 1996. Management Accounting Systems design and its Interaction with Task Uncertainty and Locus of control on Managerial Performance.

Chong, V.K and Kar Ming Chong. 1997. Strategic Choices, Environmental Uncertainty and SBU Performance: A Note of the Intervening Role of Management Accounting Systems. Accounting and Business Research, Vol. 27 No.4. pp.268-276.

Chong, VK., Ian RC. Eggleton and Michele Leong. 2001. The Impact of Market Competition and Budgetary Participation on Performance and Job Satisfaction: Evidence from The Australian Banking and Financial Services Sectors. The 2000 AsianPacific Conference on International Accounting Issues, Beijing, China.

Cooper, Donald R. and Pamela S. Schindler. 2003. Busines Research Methods. Eight Edition, New York: McGraw-Hill Companies, Inc. 
Desmiyawati. 2001. Pengaruh Strategi Bisnis and Ketidakpastian Lingkungan terhadap Hubungan antara Karakteristik Informasi Broad Scope Sistem Akuntansi Manajemen dengan Kinerja Organisasi. Thesis (tidak dipublikasikan), Program Pasca Sarjana UGM, Jogjakarta.

Dewar, R. and Werbel, J. 1979. Universalistic and contingency predictions of employee satisfaction and conflict. Administrative Science Quarterly, pp. 313-327.

Faisal. 2006. Analisis Pengaruh Intensitas Persaingan and Variable Kontekstual terhadap Penggunaan Informasi Sistem Akuntansi Manajemen and Business unit performance dengan Pendekatan Partial Least Square. Simposium Nasional Akuntansi IX.

Gordon, LA. and Miller, D. 1976. A Contingentigency Framework For The Design Of Accounting Information System. Accounting, Organization and Society, Vol.1, pp.59-69.

Gordon, LA. and Narayan, VK. 1984. Management Accounting Systems, Perceived Environmental Uncertainty and Organizational Structure: an Empirical Investigation. Accounting, Organization and Society, Vol.9, pp.33-47.

Gul, FA. 1991. The Effect of Managements Accounting Systems, Perceived Environmental Uncertainty on Small Business Managerial Performance. Accounting and Business Research, Vol.22, pp.57-61.

Gul, FA. and Yew, MC. 1994. The Effect of Managements Accounting Systems, Perceived Environmental Uncertainty and Decentralization on Managerial Performance: A Test of Three-Way Interaction. Accounting Organization and Society, Vol.19, No.4/5, pp.413-426.

Ikhsan, Arfan. 2006. Pengaruh Intensitas Persaingan Pasar terhadap Kinerja Unit Perusahaan: Informasi Sistem Akuntansi Manajemen sebagai Variabel Intervening. Jurnal Bisnis dan Akuntansi, Vol. 8, No. 2 pp.151-171.

Iselin, E. R. 1988. The Effect of Information Load and Information Diversity on Decision Quality in the Structured Decision Task. Accounting, Organization and Society, 13(2). pp.147-164.

Jiambalvo, J. and Pratt, J. 1982. Task Complexity and Leadership Effectiveness in CPA Firms. The Accounting Review, Vol.57, No.4.

Khandawalla, P. 1972. The Effect of Diffrent Types of Competition on the Use of Management Control. Journal of Accounting Research. pp.275-285.

Luthans, Fred. 1998. Organizational Behavior. Eight Edition: Irwin McGrawHill.

Linn, T.A. 1994. Learning from the Competition, Journal of Accountancy. February, pp.4346.

Mardiyah, Aida Ainul and Gudono. 2001. Pengaruh Ketidakpastian Lingkungan and Desentralisasi terhadap karakteristik Sistem Akuntansi managemen. Jurnal Riset Akuntansi Indonesia 4(1). pp.1-30.

Mia, L and Brian Clarke. 1999. Market Competition, Management Accounting Systems and Business Unit Performance. Management Accounting Research, Vol.10. pp.137158.

Nizarudin, Abu. 2006. Pengaruh Strategi Customization terhadap Kinerja Perusahaan melalui Penggunaan Karakteristik Informasi Sistem Akuntansi Manajemen yang Bersifat Broad Scope and Aggregation. Simposium Nasional Akuntansi IX. 
Nurnaluri, Srithi. 2005. Ketidakpastian Tugas and Budaya Organisasi sebagai Variable Pemoderasi terhadap hubungan antara penggunaan Informasi Akuntansi dengan Kinerja Managerial. Thesis (tidak dipublikasikan), Program Pasca Sarjana UGM, Jogjakarta.

Otley. 1980. The Contigency Theory of Management Accounting: Achievement and Prognosis. Accounting Organization and Society, Vol.5, No.4, pp.413-428.

Porter, M.E. 1980. How Competitive Forces Shape Strategy. Harvard Business Review. March/April. pp.137-145.

Riyanto, Bambang. 1999. Identifikasi Isu Penelitian Akuntansi Manajemen: Pendekatan Kontinjensi. Media Akuntansi, No.34/Th.VI April.

Riyanto, Bambang. 2003. An Examination of the Impact of the Fit between Strategic Uncertainty and Management Accounting Systems on Financial Performance. Jurnal Riset Akuntansi Indonesia, Vol.6, No.3, September, pp.288-303.

Rolfe, A.J. 1992. Profitability, Reporting Techniques Bridge Information Gap. The Journal of Business Strategy. pp.32-37.

Simons, R. 1987. Accounting Control Systems and Business Strategy: An Empirical Analysis. Accounting, Organization and Society, Vol.12, No.4, pp.357-374.

Supardiyono, YP. 1999. Pengaruh Ketidakpastian Lingkungan and Struktur Organisasi terhadap Efektifitas Sistem Akuntansi Managemen dalam peningkatan Kinerja Managerial. Thesis (tidak dipublikasikan), Program Pasca Sarjana UGM, Jogjakarta.

Susanto, Y. Kurnia and Gudono. 2007. Pengaruh Intensitas Kompetisi Pasar terhadap Hubungan antara Penggunaan Informasi Sistem Akuntansi Managemen dan Kinerja Unit Bisnis dan Kepuasan Kerja. Jurnal Bisnis dan Akuntansi, Vol. 9, No. 3, pp.177-198.

Susanto, Y. Kurnia. 2008. Pengaruh Ketidakpastian Tugas terhadap Hubungan antara Informasi Sistem Akuntansi Managemen dan Kinerja Managerial. Jurnal Akuntansi dan Bisnis, Vol. 8, No. 1, pp.15-24. 
Halaman ini sengaja dikosongkan 